\title{
Spectrum of Histomorphological Changes in Lungs at Autopsy: A 5 Year Study
}

\author{
Rupali Ramrao Kurawar* and Maya Suresh Vasaikar
}

Dept. of Pathology, Shree Bhausaheb Hire Govt. Medical College, Dhule, Maharashtra, India

\section{ABSTRACT}

Background: An autopsy is an essential and most beneficial way to find out state of the internal organs. Various inflammatory, neoplastic and other lesions along with almost all forms of terminal diseases complicate lungs. Autopsy can disclose the disease that may not be suspected clinically or may offer understanding of previous disease.

Methods: This is the non-interventional record based cross-sectional study done in the Department of Pathology of North Maharashtra regional center. Cases were included irrespective of their age and sex. 1263 cases were studied during the period of January 2011 to December 2015. Gross and microscopic features were documented.

Result: Amongst 1263 cases studied during the period of five years, maximum cases were seen in 20-29 years of age group. Males were more commonly affected $(56.13 \%)$ compared to females $(43.86 \%)$. Terminal changes like pulmonary edemaand changes due to cardiac causes were most commonly (58.82\%) seen in lungs at autopsy, followed by pneumonia (19.16\%). Sickle cell disease, tuberculosis, acute respiratory distress syndrome and mycotic abscess accounted for $3.24 \%, 2.53 \%, 0.55 \%$ and $0.23 \%$ cases respectively. $0.39 \%$ cases showed metastatic lung cancer. Among the cases of pneumonia, interstitial pneumonia was most common (42.56\%), presented most commonly in 20-29 years of age group with male preponderance $(22.31 \%)$.

Conclusion: Autopsy remains vital even after significant progress in diagnostic technologies. It is an important complimentary tool in identifying and understanding respiratory diseases that also helps in evaluating the disease process. Histomorphological studies of lungs at autopsy may reveal various diseases and their relative input towards death.

Keywords: Lung Autopsy, Histomorphological Changes, Pneumonia, Tuberculosis, Terminal Changes, Chronic Respiratory Diseases.

\section{Introduction}

An autopsy is a medical practice that consists of a thorough examination performed on a body after death. It is also helpful in evaluating disease or injury of a person and also determines the cause and manner of a person's death. An autopsy is required in deaths having medico-legal issues or in deaths where the cause is not established. $^{[1,2]}$ Thus autopsy helps to study process in situ and enriches medical knowledge. ${ }^{[1,3]}$ Autopsy is an important and most valuable way to find out the state of internal organs. ${ }^{[4]}$ The Autopsy may disclose diagnosis which may not be presumed clinically or may, in some way, discredit. ${ }^{[1,5]}$ In addition to ascertain clinico-pathological differences, autopsy has a role in the development of new understanding of old diseases and facilitate the opportunity to discover new diseases. ${ }^{[4]}$

Chronic respiratory diseases are a group of chronic diseases affecting the airways and the other structures of lungs. ${ }^{[2][6]}$ Millions of people all over the world suffer from preventable chronic respiratory diseases. ${ }^{[2][7][8]}$ The clinical and radiological findings in pulmonary diseases may be nonspecific and prompt pathological investigations and diagnoses are essential to enhance patient survival, to avoid the rapid progression of the disease and to spare the patient from more invasive procedures. ${ }^{[2][7]}$ Despite recent advances, most types of diagnostic supports are still expensive. ${ }^{[2]}$

Therefore, it is important to define the leading causes of death to launch correct prophylactic actions, which is the least expensive strategy for preventing further pulmonary dysfunction and circumvent the need for lung biopsies. ${ }^{[2][7][9]}$

Pathologic examination of autopsy lungs gives valuable information such as various stages of fibrosis, honey combing lesions with their distribution and progression in the lungs. ${ }^{[2]}$

The aim of this study was to present the pulmonary histopathological alterations identified in autopsies of patients who died from respiratory diseases or other causes with pulmonary involvement as well as to throw a light on principal causes of death due to pulmonary involvement.

\section{Materials And Methods}

This non-interventional, record based cross-sectional study was conducted at the department of Pathology of 
North Maharashtra regional center. The duration of study was five year, from January 2011 to December 2015. The study was conducted on 1263 specimens of lung tissues that were received at our department. All autopsy subjects regardless of age and sex were included in this study where lung tissue was provided.

The lung tissue was fixed in 10\% formalin. Paraffin embedded tissue sections ( $5 \mathrm{~mm}$ thick) were assessed using haematoxylin and eosin stain. All the histological sections were examined microscopically \& findings were recorded. Special stains were done wherever necessary.

\section{Result}

During the period of January 2011 to December 2015, a total of 1263 specimens of lung tissue were received and studied at our regional center. Following observations were noted. Most common age group of lung involvement was 20-29 years(i.e. in $21.61 \%$ cases) (Table-1). Males were more commonly $(56.13 \%)$ affected compared to females $(43.86 \%)($ Table-3).

Majority i.e. $743(58.82 \%)$ of cases showed terminal changes in lung at histopathology like pulmonary edema, mild inflammatory infiltrate and changes due to cardiac causes. This was followed by pneumonia (Figure-1) contributing to about $19.16 \%$ (i.e. 242 cases). In 152 , i.e. $12.03 \%$ cases the lung tissue was autolysed. Lung involvement in sickle cell disease (SCD) (Figure-2) was seen in $41(3.24 \%$ ) cases. Tuberculosis (Figure-3) impacted 32 cases making $2.53 \%$ contribution to the total 1263 cases. In 29 (2.29\%) cases lungs showed normal histology. Death due to acute respiratory distress syndrome (ARDS) (Figure-4) was seen in $0.55 \%$ (i.e. 7) cases. $5(0.39 \%)$ cases showed evidence of metastasis out of which 3 were from leukemia and the remaining 2 were from squamous cell carcinoma of tongue (Figure-5)andclear cell variant of renal cell carcinoma (Figure-6). In three cases $(0.23 \%)$ mycotic abscess (Figure-7) was seen due to fungal infection of lungs and in two cases $(0.15 \%)$ malarial pigments were noted.(Table-1)

Highest no. of cases of pneumonia were seen in 2029 years of age group. Among all cases of pneumonia maximum cases (103) were that of interstitial pneumonia contributing to $42.56 \%$. This was followed by lobar pneumonia (70 cases) making $28.92 \%$ input to all types of pneumonias and bronchopneumonia ( 67 cases) formulating $27.68 \%$ cases (Table-2). Maximum cases of interstitial pneumonia were seen in 20-29 years of age group and that of lobar pneumonia were seen in 20-39 years of age group. Maximum cases of bronchopneumonia were seen in 20
-29 years of age group. There was one case of aspiration pneumonia and one case of fibrosing alveolar pneumonia (Table-2). Among 242 (19.16\%) cases of pneumonia $141(11.16 \%)$ cases were males and $101(7.99 \%)$ cases were females (Table-3). In interstitial pneumonia 54 among 103 (i.e. $22.31 \%)$ cases were males and $49(20.24 \%)$ cases were females. $20.24 \%$ (i.e. 49 ) cases of lobar pneumonia were seen in males while in 21 cases $(8.67 \%)$ females were affected. Males showed $14.87 \%$ frequency (36 cases) of bronchopneumonia and that of females showed $12.80 \%$ (31 cases) (Table-4). Excluding pulmonary involvement in terminal stages, pneumonia was the most common disease involving lungs in both males and females. In our study 141 cases of pneumonia were seen in males out of total 709 cases affecting males which constituted $19.88 \%$ and 101 cases in females out of total 554 cases affecting females that constituted $18.23 \%$ (Table-3). Interstitial pneumonia was the leading cause of lung involvement at autopsy among all types of pneumonias in both males and females affecting $54(38.29 \%)$ cases in males out of 141 and 49 (48.51\%) cases in females out of 101 (Table-4).

Pulmonary involvement due to sickle cell disease was commonly seen in 20-29 years of age group constituting $1.66 \%$ (i.e. 21) cases. Females were more frequently affected compared to males i.e. in $24(1.90 \%)$ cases among 41 (Table- 1, 3).Tuberculosis was seen with peak incidence in 40-49 years of age group. In $22(1.74 \%)$ cases males were affected by tuberculosis and in $10(0.79 \%)$ cases females were affected (Table-1,3). Among 7 cases of ARDS, maximum i.e. $2(0.15 \%)$ cases were seen in $0-9$ years of age group with a similar frequency in 20-29 years of age group and in 6 cases females were affected formulating $0.47 \%$ of all lung lesions (Table-1,3). In metastatic lung involvement the leukemic infiltration cases were seen in 10-19 years of age group with male preponderance, one case of 65 years of male with metastasis to lungs from clear cell variant of renal cell carcinoma (Figure-6) and another case of 39 years male with metastasis from squamous cell carcinoma of tongue (Figure-5) (Table- 1, 3).

Out of 3 cases of mycotic abscess (Figure-4) 2 cases were seen in 30-39 years of age group with male preponderance $(0.15 \%$ cases $)$. Bronchiectasis and chronic bronchitis were seen in $4(0.31 \%)$ and $3(0.23 \%)$ cases respectively and are more commonly found in $\geq 60$ years and $20-29$ years of age group in that order. There was no sex predilection in cases of bronchiectasis while males are commonly affected in chronic bronchitis (Table-1, 3). Females in 20-39 years of age group showed more frequency of malarial pigments in lung tissue compared to males (Table- 1, 3). 
Table 1: Age wise distribution of Pulmonary lesions (n-1263).

\begin{tabular}{|c|c|c|c|c|c|c|c|c|}
\hline \multirow{2}{*}{ Pulmonary lesion } & \multicolumn{8}{|c|}{ Age (Years) } \\
\hline & $0-9$ & $10-19$ & $20-29$ & $30-39$ & $40-49$ & $50-59$ & $\geq 60$ & Total \\
\hline Terminal changes & $\begin{array}{c}50 \\
(3.95)\end{array}$ & $\begin{array}{c}65 \\
(5.14)\end{array}$ & $\begin{array}{c}138 \\
(10.92)\end{array}$ & $\begin{array}{c}150 \\
(11.87)\end{array}$ & $\begin{array}{c}118 \\
(9.34)\end{array}$ & $\begin{array}{c}112 \\
(8.86)\end{array}$ & $\begin{array}{c}110 \\
(8.70)\end{array}$ & $\begin{array}{c}743 \\
(58.82)\end{array}$ \\
\hline Pneumonia & $\begin{array}{c}33 \\
(2.61)\end{array}$ & $\begin{array}{c}21 \\
(1.66)\end{array}$ & $\begin{array}{c}66 \\
(5.22)\end{array}$ & $\begin{array}{c}43 \\
(3.40)\end{array}$ & $\begin{array}{c}35 \\
(2.77)\end{array}$ & $\begin{array}{c}21 \\
(1.66)\end{array}$ & $\begin{array}{c}23 \\
(1.82)\end{array}$ & $\begin{array}{c}242 \\
(19.16)\end{array}$ \\
\hline Autolysed specimen & $\begin{array}{c}9 \\
(0.71)\end{array}$ & $\begin{array}{c}23 \\
(1.82)\end{array}$ & $\begin{array}{c}30 \\
(2.37)\end{array}$ & $\begin{array}{c}32 \\
(2.53)\end{array}$ & $\begin{array}{c}25 \\
(1.97)\end{array}$ & $\begin{array}{c}16 \\
(1.26)\end{array}$ & $\begin{array}{c}17 \\
(1.34)\end{array}$ & $\begin{array}{c}152 \\
(12.03)\end{array}$ \\
\hline SCD & $0(0)$ & $14(1.10)$ & $21(1.66)$ & $2(0.15)$ & $3(0.23)$ & $1(0.07)$ & $0(0)$ & $41(3.24)$ \\
\hline Tuberculosis & $2(0.15)$ & $2(0.15)$ & $4(0.31)$ & $4(0.31)$ & $10(0.79)$ & $5(0.39)$ & $5(0.39)$ & $32(2.53)$ \\
\hline Normal Histology & $\begin{array}{c}2 \\
(0.15)\end{array}$ & $\begin{array}{c}5 \\
(0.39)\end{array}$ & $\begin{array}{c}8 \\
(0.63)\end{array}$ & $\begin{array}{c}6 \\
(0.47)\end{array}$ & $\begin{array}{c}2 \\
(0.15)\end{array}$ & $\begin{array}{c}4 \\
(0.31)\end{array}$ & $\begin{array}{c}2 \\
(0.15)\end{array}$ & $\begin{array}{c}29 \\
(2.29)\end{array}$ \\
\hline ARDS & $2(0.15)$ & $0(0)$ & $2(0.15)$ & $1(0.07)$ & $1(0.07)$ & $1(0.07)$ & $0(0)$ & $7(0.55)$ \\
\hline Malignancy & $0(0)$ & $2(0.15)$ & $1(0.07)$ & $1(0.07)$ & $0(0)$ & $0(0)$ & $1(0.07)$ & $5(0.39)$ \\
\hline Bronchiectasis & $0(0)$ & $0(0)$ & $0(0)$ & $1(0.07)$ & $0(0)$ & $1(0.07)$ & $2(0.15)$ & $4(0.31)$ \\
\hline Chronic bronchitis & $\begin{array}{c}0 \\
(0)\end{array}$ & $\begin{array}{c}0 \\
(0)\end{array}$ & $\begin{array}{c}2 \\
(0.15)\end{array}$ & $\begin{array}{c}1 \\
(0.07)\end{array}$ & $\begin{array}{c}0 \\
(0)\end{array}$ & $\begin{array}{c}0 \\
(0)\end{array}$ & $\begin{array}{c}0 \\
(0)\end{array}$ & $\begin{array}{c}3 \\
(0.23)\end{array}$ \\
\hline Mycotic abscess & $0(0)$ & $0(0)$ & $0(0)$ & $2(0.15)$ & $0(0)$ & $1(0.07)$ & $0(0)$ & $3(0.23)$ \\
\hline Malaria & $0(0)$ & $0(0)$ & $1(0.07)$ & $1(0.07)$ & $0(0)$ & $0(0)$ & $0(0)$ & $2(0.15)$ \\
\hline Total & $\begin{array}{c}98 \\
(7.75)\end{array}$ & $\begin{array}{c}132 \\
(10.45)\end{array}$ & $\begin{array}{c}273 \\
(21.61)\end{array}$ & $\begin{array}{c}244 \\
(19.31)\end{array}$ & $\begin{array}{c}194 \\
(15.36)\end{array}$ & $\begin{array}{c}162 \\
(12.82)\end{array}$ & $\begin{array}{c}160 \\
(12.66)\end{array}$ & $\begin{array}{l}1263 \\
(100)\end{array}$ \\
\hline
\end{tabular}

(ARDS- Acute respiratory distress syndrome; SCD- Sickle cell disease)

Table 2: Age wise distribution of Pneumonias (n-242).

\begin{tabular}{|c|c|c|c|c|c|c|c|c|}
\hline \multirow{2}{*}{ Type of pneumonia } & \multicolumn{8}{|c|}{ Age in years (\%) } \\
\hline & $0-9$ & $10-19$ & $20-29$ & $30-39$ & $40-49$ & $50-59$ & $\geq 60$ & Total \\
\hline Interstitial pneumonia & $\begin{array}{c}9 \\
(3.71) \\
\end{array}$ & $\begin{array}{c}7 \\
(2.89) \\
\end{array}$ & $\begin{array}{c}32 \\
(13.22)\end{array}$ & $\begin{array}{c}18 \\
(7.43) \\
\end{array}$ & $\begin{array}{c}15 \\
(6.19) \\
\end{array}$ & $\begin{array}{c}15 \\
(6.19) \\
\end{array}$ & $\begin{array}{c}7 \\
(2.89)\end{array}$ & $\begin{array}{c}103 \\
(42.56)\end{array}$ \\
\hline Lobar Pneumonia & $\begin{array}{c}12 \\
(4.95) \\
\end{array}$ & $\begin{array}{c}9 \\
(3.71) \\
\end{array}$ & $\begin{array}{c}14 \\
(5.78)\end{array}$ & $\begin{array}{c}14 \\
(5.78) \\
\end{array}$ & $\begin{array}{c}12 \\
(4.95) \\
\end{array}$ & $\begin{array}{c}3 \\
(1.23) \\
\end{array}$ & $\begin{array}{c}6 \\
(2.47) \\
\end{array}$ & $\begin{array}{c}70 \\
(28.92) \\
\end{array}$ \\
\hline Bronchopneumonia & $\begin{array}{c}12 \\
(4.95) \\
\end{array}$ & $\begin{array}{c}4 \\
(1.65) \\
\end{array}$ & $\begin{array}{c}15 \\
(6.19) \\
\end{array}$ & $\begin{array}{c}11 \\
(4.54) \\
\end{array}$ & $\begin{array}{c}7 \\
(2.89) \\
\end{array}$ & $\begin{array}{c}8 \\
(3.30) \\
\end{array}$ & $\begin{array}{c}10 \\
(4.13) \\
\end{array}$ & $\begin{array}{c}67 \\
(27.68) \\
\end{array}$ \\
\hline Aspiration pneumonia & $\begin{array}{c}1 \\
(0.41) \\
\end{array}$ & $\begin{array}{c}0 \\
(0)\end{array}$ & $\begin{array}{c}0 \\
(0)\end{array}$ & $\begin{array}{c}0 \\
(0)\end{array}$ & $\begin{array}{c}0 \\
(0)\end{array}$ & $\begin{array}{c}0 \\
(0)\end{array}$ & $\begin{array}{c}0 \\
(0)\end{array}$ & $\begin{array}{c}1 \\
(0.41)\end{array}$ \\
\hline $\begin{array}{l}\text { Fibrosing alveolar } \\
\text { pneumonia }\end{array}$ & $\begin{array}{c}0 \\
(0) \\
\end{array}$ & $\begin{array}{c}0 \\
(0)\end{array}$ & $\begin{array}{c}0 \\
(0) \\
\end{array}$ & $\begin{array}{c}0 \\
(0) \\
\end{array}$ & $\begin{array}{c}0 \\
(0)\end{array}$ & $\begin{array}{c}1 \\
(0.41) \\
\end{array}$ & $\begin{array}{c}0 \\
(0) \\
\end{array}$ & $\begin{array}{c}1 \\
(0.41) \\
\end{array}$ \\
\hline Total & $\begin{array}{c}34 \\
(14.04)\end{array}$ & $\begin{array}{c}20 \\
(8.26)\end{array}$ & $\begin{array}{c}61 \\
(25.20)\end{array}$ & $\begin{array}{c}43 \\
(17.76)\end{array}$ & $\begin{array}{c}34 \\
(14.04)\end{array}$ & $\begin{array}{c}27 \\
(11.15)\end{array}$ & $\begin{array}{c}23 \\
(9.50)\end{array}$ & $\begin{array}{c}242 \\
(100)\end{array}$ \\
\hline
\end{tabular}

Table 3: Sex wise distribution of Pulmonary lesions (n-1263).

\begin{tabular}{|l|c|c|c|}
\hline \multirow{2}{*}{ Pulmonary lesion } & \multicolumn{3}{|c|}{ Sex (\%) } \\
\cline { 2 - 4 } & Male & Female & Total \\
\hline Terminal changes & $425(33.65)$ & $318(25.17)$ & $\mathbf{7 4 3 ( 5 8 . 8 2 )}$ \\
\hline Pneumonia & $141(11.16)$ & $101(7.99)$ & $\mathbf{2 4 2 ( 1 9 . 1 5 )}$ \\
\hline
\end{tabular}




\begin{tabular}{|l|c|c|c|}
\hline \multirow{2}{*}{ Pulmonary lesion } & \multicolumn{3}{|c|}{ Sex (\%) } \\
\cline { 2 - 4 } & Male & Female & Total \\
\hline Autolysed specimen & $77(6.09)$ & $75(5.93)$ & $\mathbf{1 5 2 ( 1 2 . 0 2 )}$ \\
\hline SCD & $17(1.34)$ & $24(1.90)$ & $\mathbf{4 1 ( 3 . 2 4 )}$ \\
\hline Tuberculosis & $22(1.74)$ & $10(0.79)$ & $\mathbf{3 2 ( 2 . 5 3 )}$ \\
\hline Normal Histology & $16(1.26)$ & $13(1.02)$ & $\mathbf{7 ( 0 . 5 5 )}$ \\
\hline ARDS & $1(0.08)$ & $6(0.47)$ & $\mathbf{5 ( 0 . 3 9 )}$ \\
\hline Malignancy & $4(0.31)$ & $1(0.08)$ & $\mathbf{4 ( 0 . 3 )}$ \\
\hline Bronchiectasis & $2(0.15)$ & $2(0.15)$ & $\mathbf{3 ( 0 . 2 3 )}$ \\
\hline Chronic bronchitis & $2(0.15)$ & $1(0.08)$ & $\mathbf{3 ( 0 . 2 3 )}$ \\
\hline Mycotic abscess & $2(0.15)$ & $1(0.08)$ & $\mathbf{2 ( 0 . 1 5 )}$ \\
\hline Malaria & $0(0)$ & $2(0.15)$ & $\mathbf{1 2 6 3 ( 1 0 0 )}$ \\
\hline Total & $\mathbf{7 0 9 ( 5 6 . 1 3 )}$ & $\mathbf{5 5 4 ( 4 3 . 8 6 )}$ & \\
\hline
\end{tabular}

Table 4: Sex wise distribution of Pneumonias (n-242).

\begin{tabular}{|l|c|c|c|}
\hline \multirow{2}{*}{ Type of pneumonia } & \multicolumn{3}{|c|}{ Sex (\%) } \\
\cline { 2 - 4 } & Male & Female & Total \\
\hline Interstitial pneumonia & $54(22.31)$ & $49(20.24)$ & $\mathbf{1 0 3 ( 4 2 . 5 5 )}$ \\
\hline Lobar Pneumonia & $49(20.24)$ & $21(8.67)$ & $\mathbf{7 0 ( 2 8 . 9 1 )}$ \\
\hline Bronchopneumonia & $36(14.87)$ & $31(12.80)$ & $\mathbf{6 7 ( 2 7 . 6 7 )}$ \\
\hline Aspiration pneumonia & $1(0.41)$ & $0(0)$ & $\mathbf{1 ( 0 . 4 1 )}$ \\
\hline Fibrosing alveolar pneumonia & $1(0.41)$ & $0(0)$ & $\mathbf{1 ( 0 . 4 1 )}$ \\
\hline Total & $\mathbf{1 4 1 ( 5 8 . 2 6 )}$ & $\mathbf{1 0 1 ( 4 1 . 7 3 )}$ & $\mathbf{2 4 2 ( 1 0 0 )}$ \\
\hline
\end{tabular}

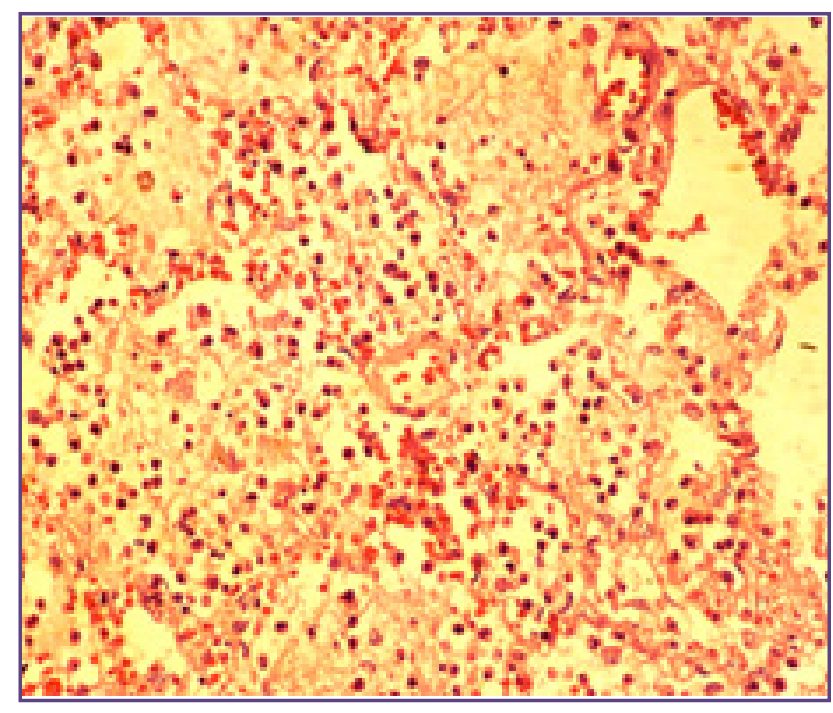

Fig. 1: Shows intra-alveolar exudate of polymorphonuclear cells, red cells and fibrin with congested septal capillaries (Pneumonia, stage of red hepatisation), 40X, H \& E stain.

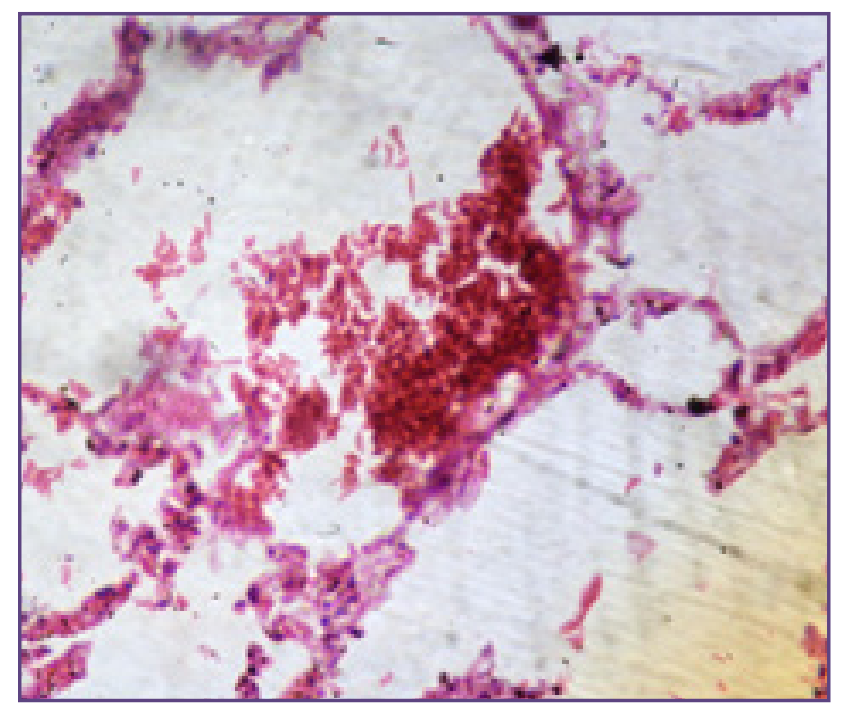

Fig. 2: Showing congested interstitial blood vessels and alveoli studded with sickled RBCs (Lung involvement in sickle cell disease), 40X, H \& E stain. 


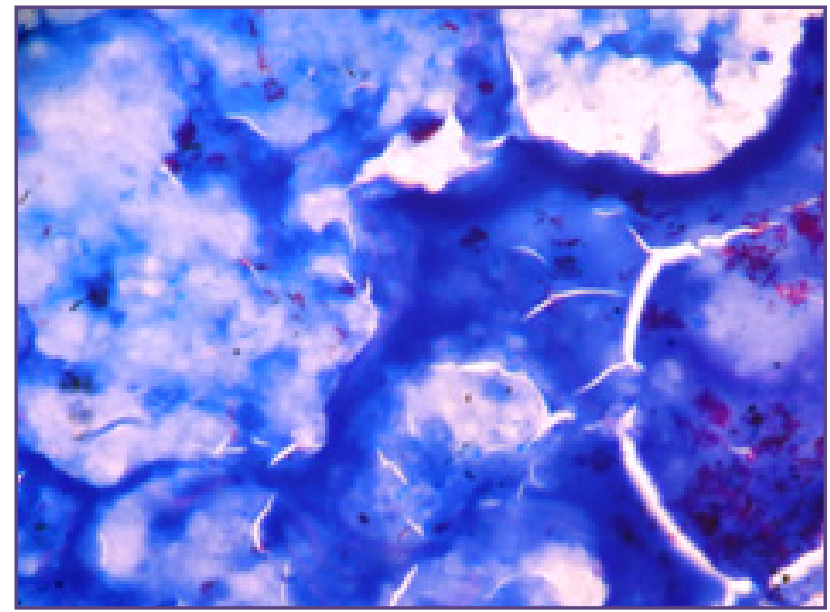

Fig. 3: Shows singly scattered and many clusters of slender and beaded ZN (Zeihl Neelsen) positive tubercular bacilli, 40X, ZN stain.

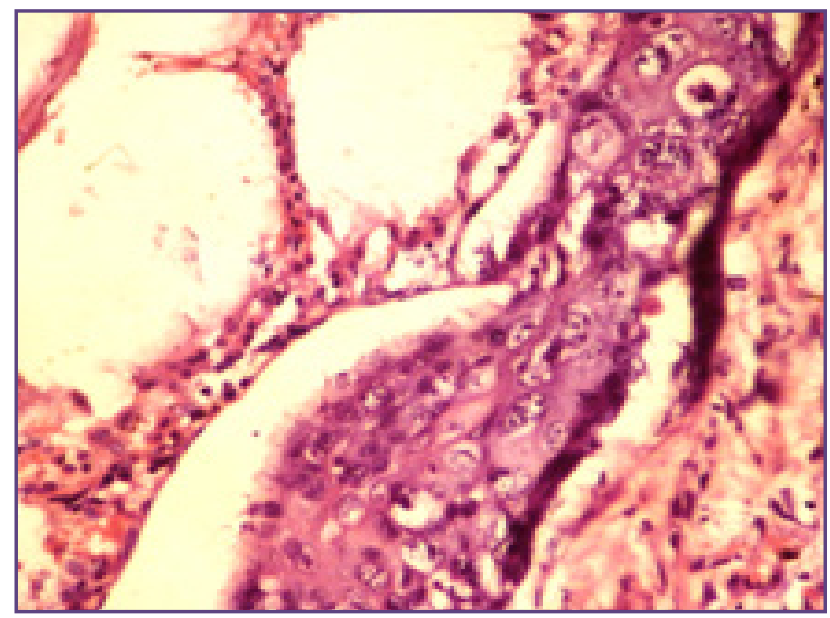

Fig. 5: Show islands of malignant squamous epithelial cells metastasized to lung tissue, 40X, H \& E stain.

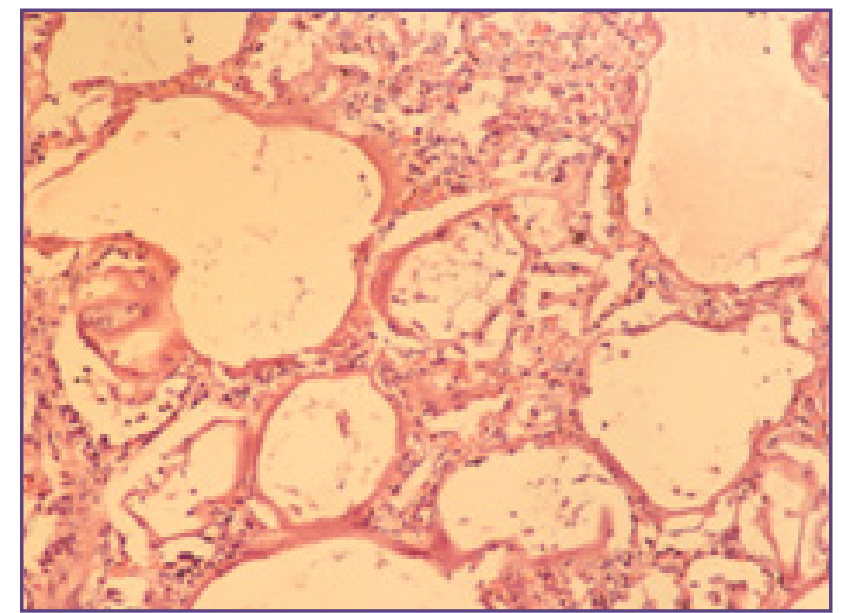

Fig. 4: shows few collapsed alveoli and few distended alveoli lined by hyaline membrane with intra-alveolar edema and interstitial inflammatory infiltrate. (Acute respiratory distress syndrome), 40x, H \& E stain.

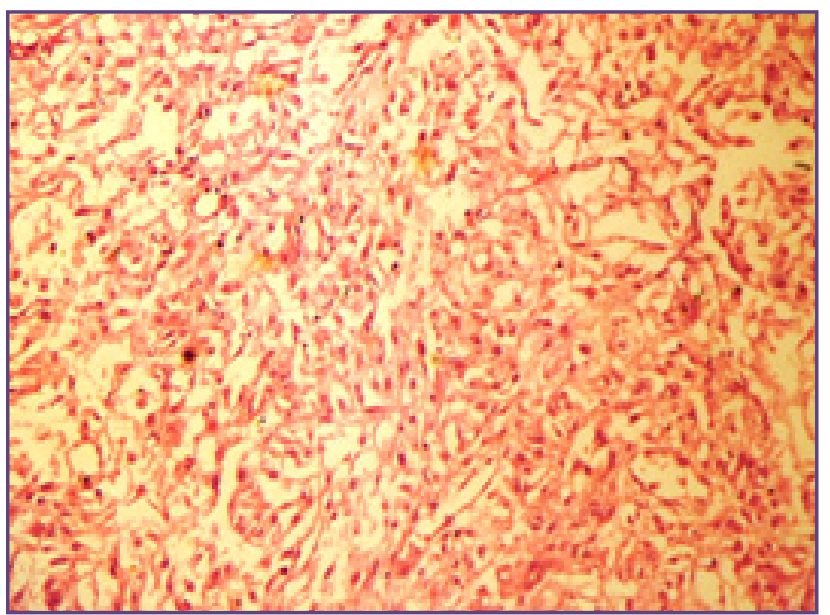

Fig. 6: Metastasis from clear cell variant of renal cell carcinoma to lungs, 40X, H \& E stain.

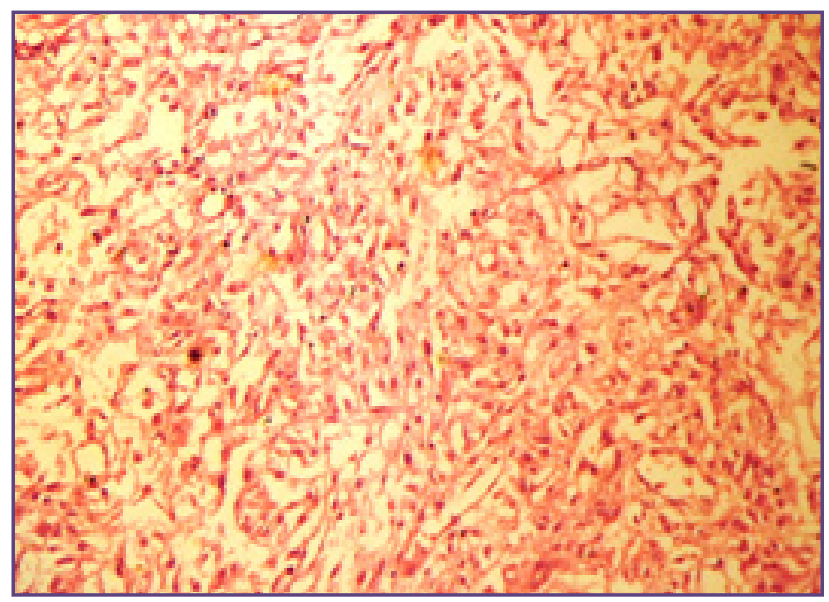

Fig. 7: Fungal ball showing septate hyphae with acute angle branching and surrounding inflammatory cell infiltrate (Aspergillus infection), 40X, H \& E stain. 


\section{Discussion}

In our study, terminal changes in lung due to extra pulmonary cause of death like pulmonary edema, congestion, interstitial inflammatory infiltrate and ARDS, all falling under acute lung injury, accounted for $58.82 \%$ (i.e. 743 cases) of all cases, thus forming the bulk of pulmonary pathology in autopsy cases. These observations are in agreement with those of Chauhan et al $(2015)^{[7]}$ who reported $54.32 \%$ cases of terminal changes in lungs which included interstitial edema, congestion and changes due to cardiovascular causes, Bora Ozdemir et al (2012) ${ }^{[10]}$ who found intra alveolar hemorrhage and pulmonary edema together accounting for $71.2 \%$ of the cases, Alexandre de MS et al ${ }^{[}$

${ }^{11]}$ whose study revealed intra alveolar edema, pulmonary congestion and diffuse alveolar damage in $77.7 \%$ of the cases and $\mathrm{Bal}$ et al $2008^{[5]}$ who reported $59.3 \%$ cases of terminal events in lung like pulmonary edema and ARDS. Male dominance was seen in terminal changes in lung in our study similar to other studies as stated above. ${ }^{[5][7][10]}$

Among all cases in our study, the second most common cause of death was pneumonia. There were 242 cases of pneumonia constituting $19.16 \%$. This finding was comparable to study done by Bal et $\mathrm{a}^{[5]}$, Niazi et $\mathrm{al}^{[122]}$, Fang et al ${ }^{[13]}$ and Chauhanet al ${ }^{[7]}$ who found $18 \%$, $17.88 \%, 15 \%, 14.62 \%$ cases of pneumonia at autopsy in their studies. Males were more commonly affected by pneumonia (11.16\%) compared to females in our study similar to the findings of Chauhan et $\mathrm{al}^{[7]}$ and $\mathrm{Bal}$ et al ${ }^{[5]}$ who also reported male preponderance. The most common age group affected in our study is below 50 years of age similar to findings of Tahir et a ${ }^{[2]}$, while in study done by Chauhan et al ${ }^{[7]}$, majority of cases were seen in $6^{\text {th }}$ and $7^{\text {th }}$ decade of life. This difference can be due to small number of total cases in Chauhan et al study. In our study, we found interstitial pneumonia as most common type $(42.56 \%)$ of pneumonia followed by lobar pneumonia $(28.92 \%)$ and bronchopneumonia (27.68\%). Males were commonly affected compared to females in all types of pneumonias and the most common age group was $3^{\text {rd }}$ and $4^{\text {th }}$ decade of life (Table-2, 4).

We found tuberculosis in $32(2.53 \%)$ cases out of 1263 cases studied, of which, majority i.e. $22(1.74 \%)$ cases were males and the commonest age group was $40-49$ years. Our study was in agreement with Selvam et a ${ }^{[14]}$ study who found $2.8 \%$ cases of tuberculosis in their study. Tahir et $\mathrm{a}^{[2]}$ in their study found $19 \%$ cases of tuberculosis with male preponderance and most of them were below 50 years of age group. The difference in the total percentage of tuberculosis can be explained by specific specimen of lungs with hilar lymph nodes were studied by Tahir et al. Garg et al ${ }^{[15]}$ found $8.7 \%$ cases of active tuberculosis at autopsy with male dominance similar to our study.

Our study revealed $0.39 \%$ (i.e. 5) cases of pulmonary involvement in malignancy with male preponderance (i.e. 4 cases accounting to $0.31 \%$ in males vs. $0.08 \%$ cases in females). Three cases were in 10-29 years of age group, one was in30-39 years of age group and the last one was above 60 years of age. Chauhan et $\mathrm{a}^{\left[{ }^{7]}\right.}$ found $7(2.08 \%)$ cases of malignant pulmonary lesions in their study, most commonly occurring in males $(1.79 \%)$ above the age of 50 years.

In the rest of the cases, we found $29(2.29 \%)$ cases with normal histology of lung. There were $3(0.23 \%)$ cases of mycotic abscess, $4(0.31 \%)$ cases of bronchiectasis and $3(0.23 \%)$ cases of chronic bronchitis. Malarial pigments were seen in $2(0.15 \%)$ cases. In $41(3.24 \%)$ cases blood vessels in lungs showed sickled RBCs, maximum cases of which were seen in 10-29 years of age group with female dominance $(1.90 \%)$.

\section{Conclusion}

Despite recent advances in diagnostic technology, the autopsy has endured as a vital complimentary tool for recognizing and understanding chronic respiratory diseases. It also serves as reassuring and educative tool in identifying and establishing the underlying cause of death. Autopsy study is of great value in refining the vision and diagnostic setup for better clinical evaluation. Histomorphological study of lung in autopsies may quite often disclose common diseases affecting lungs and their relative contribution towards death.

\section{Abbreviations \& Symbols}

ARDS- Acute respiratory distress syndrome

SCD- sickle cell disease

\section{Acknowledgements}

We are thankful to Mr. Y. B. Chavhan for his technical support. We also extend our thanks to other technical staff. We are grateful to our head of the department, Dr. Maya Vasaikar for the concept of article and her writing assistance.

\section{Reference}

1. Udayashankar SK, Shashikala P, Kavita GU, Deepti P. Histomorphogical Pattern of Lung in Medicolegal Autopsies. International Journal of Science and Research.2015;4(7):1937-39.

2. Tahir TM, Rehman F, Anwar S, Kamal F. Patterns of pulmonary morphological lesions seen at autopsy. Biomedica. 2013;29:64-8. 
3. Pathak A, Mangal HM. Histopathology examination in medico-legal autopsy pros \& cons. J Indian Acad Forensic Med. 2008;32(2):128-31.

4. Shweta, Deepti M, Vidhu M, Angmo P. Histopathological pattern in lung autopsy in Government medical college Jammu. Journal of Evolution of Medical and Dental Sciences. 2015;4(91):15694-96.

5. Bal MS, Sethi PS, Suri AK, Bodal VK, Kaur G. Histopathological pattern in lung autopsies. JPAFMAT. 2008;8(2):29-31.

6. Alexandre de MS, Aline DR, Mauro C, Edwin RP, Cec1'lia F, Vera LC. Demographic, etiological and histological pulmonary analysis of patients with acute respiratory failure: a study of 19 years of autopsies. Clinics. 2011;66(7):1193-197.

7. Chauhan G, Agrawal M, Thakkar N, Parghi B. Spectrum of histopathological lesions in lung autopsy. J Res Med Den Sci. 2015;3(2):109-12

8. Gross JS, Neufeld RR, Libow LS, Gerber I, Rodstein M. Autopsy study of the elderly institutionalized patient: Review of 234 autopsies. Arch Intern Med. 1998;148:173-6.

9. Ghosal R, Kloer P, Lewis KE. A review of novel biological tools used in screening for the early detection of lung cancer. Postgrad Med J. 2009;85:358-63.
10. Bora O, Celbis O, Onal R, Mizrak B, Karakoc Y. Multiple organ pathologies underlying in sudden natural deaths. Medicine Science. 2012;1(1):13-26.

11. Alexandre de MS, Edwin RP, Mauro C, Cecilia F, Vera LC. Pulmonary histopathological alterations in patients with acute respiratory failure: an autopsy study. J Bras Pneumol.2008;34(2).

12. Niazi S. Morphological study of pulmonary embolism in autopsy cases. [Thesis]. Lahore: University of the Punjab, 1989.

13. Fang F, Lin FR, Li HZ. Clinicopathologic analysis of organizing pneumonia in elderly autopsies. Zhonghua Bing Li Xue Za Zhi Chinese Journl of Pathology. 2004;33(2):113-16.

14. Selvam V, Thamil SR, Subramaniam PM, Vijayanath V. Prevalence of Common Disease in Lungs and Liver; A Histopathological study. Journal of Pharmaceutical and Biomedical Sciences. 2011; 12: 1-5.

15. Garg M, Aggarwal AD, Singh S, Kataria SP. Tuberculous Lesions at Autopsy. J Indian Acad Forensic Med.2011; 33(2):116-19.

*Corresponding author:

Dr. Rupali Ramrao Kurawar, Dept. of Pathology, Shree Bhausaheb Hire Govt. Medical College, Chakkarbardi, Dhule, Maharashtra-424311, India

Phone: +919689201664

Email: dr.rupalirkurawar@gmail.com

Date of Submission : 10.07.2016

Date of Acceptance : 25.12.2016

Financial or other Competing Interests: None.

Date of Publication : 24.02.2017 